\title{
Kinetics and Mechanism of Redox Reaction of Neutral Red with Nitrite Ion in Aqueous Acidic Medium
}

\author{
Ismaila Ibrahim ${ }^{1, a^{*}}$, Sulaiman Ola Idris ${ }^{1, b}$ and Ameh David Onu ${ }^{2, c}$ \\ ${ }^{1}$ Department of Chemistry, Ahmadu Bello University, Zaria-Nigeria \\ ${ }^{2}$ Department of Chemistry, Federal College of Education, Zaria-Nigeria \\ aibrahimmismaila@gmail.com, balhajisoidris@yahoo.com, cdaveonu@gmail.com
}

Keywords: Kinetics, mechanism, neutral red, nitrite ion.

Abstract. The kinetics of redox reaction of neutral red, $\mathrm{NR}^{+}$, with nitrite ion, $\mathrm{NO}_{2}{ }^{-}$, was studied in aqueous hydrochloric acid medium under pseudo-first order conditions at $25 \pm 1^{\circ} \mathrm{C}$, $\left[\mathrm{H}^{+}\right]=2.0 \times 10^{-3} \mathrm{~mol} \mathrm{dm}^{-3}, \mathrm{I}=0.1 \mathrm{~mol} \mathrm{dm}^{-3}(\mathrm{NaCl})$ and $\lambda_{\max }=525 \mathrm{~nm}$. The reaction was first order with respect to $\left[\mathrm{NR}^{+}\right],\left[\mathrm{NO}_{2}{ }^{-}\right]$and $\left[\mathrm{H}^{+}\right]$. The reaction displayed a negative Bronsted-Debye salt effect. There was no evidence of the formation of an intermediate complex of significant stability and free radicals are probably not present in the reaction. The observations above, coupled with the result of Michaelis-Menten plot suggests an outer sphere mechanism for the reaction. The reaction obeys the rate law:

$-\mathrm{d}\left[\mathrm{NR}^{+}\right] / \mathrm{dt}=\left(\mathrm{a}+\mathrm{b}\left[\mathrm{H}^{+}\right]\right)\left[\mathrm{NR}^{+}\right]\left[\mathrm{NO}_{2}^{-}\right]$

A plausible mechanism has been proposed for the reaction.

\section{Introduction}

Nitrite ion is a powerful oxidizing agent [1] and exists widely in food, natural water, and soil [2]. It is a good coordinating agent using either $\mathrm{N}$ or $\mathrm{O}$ site [3]. Redox reactions involving nitrite ions have been studied [1,3-7].

Neutral red is a eurhodin dye which finds a variety of applications in the biological system [8,9]. It is also used for the dyeing of silk, paper and cotton as well as for the production of inks [10]. Redox reactions of neutral red were investigated in aqueous media [10,11].

In spite of these and numerous other uses, redox chemistry of this dye with $\mathrm{NO}_{2}{ }^{-}$has not been reported. The present study is undertaken to obtain kinetic data with a view of gaining insight into the mechanistic pathway of this reaction.

Therefore, in this paper, we report on the kinetics and mechanisms of redox reaction of neutral red with nitrite ion.

\section{Materials and Methods.}

All the reagents used were Analar grade. Neutral red (Gurr) and Sodium nitrite (BDH) were used without further purification. Sodium chloride (M\&B) was used to maintain the ionic strength of the reaction medium. Hydrocholoric acid (Analar grade) was standardized titrimetrically using sodium carbonate. All other reagents were used as supplied.

The stoichiometry of the reaction was determined by spectrometric titration using the mole ratio method. The concentration of $\left[\mathrm{NR}^{+}\right]$was kept constant while that of $\left[\mathrm{NO}_{2}^{-}\right]$was varied in the reaction mixtures after which excess $\left[\mathrm{NR}^{+}\right]$was determined by measuring the absorbance of the solutions at $525 \mathrm{~nm}$ until a constant value was obtained. The stoichiometry was evaluated from the plot of absorbance against mole ratio [12].

The kinetic studies were carried out under pseudo-first order conditions with the $\left[\mathrm{NO}_{2}^{-}\right]$in excess over the $\left[\mathrm{NR}^{+}\right]$at $525 \mathrm{~nm},\left[\mathrm{H}^{+}\right]=2.0 \times 10^{-3} \mathrm{~mol} \mathrm{dm}{ }^{-3}, \mathrm{I}=0.1 \mathrm{~mol} \mathrm{dm}{ }^{-3}$ and $\mathrm{T}=25 \pm 1^{\circ} \mathrm{C}$. The Pseudo-first order rate plots of $\log \left(\mathrm{A}_{t}-\mathrm{A}_{\infty}\right)$ versus time were made (where $\mathrm{A}_{\infty}$ and $\mathrm{A}_{t}$ are the absorbance at the end of the reaction and at time, $\mathrm{t}$ ) and from the slopes of the plots, the pseudo-first order rate constants $\left(\mathrm{k}_{1}\right)$ were determined. The second order rate constants $\left(\mathrm{k}_{2}\right)$ were obtained using Equation 1.

$\mathrm{k}_{2}=\mathrm{k}_{1} /\left[\mathrm{NO}_{2}^{-}\right]$ 


\section{Results and Discussion}

Stoichiometric Studies. From the stoichiometric studies, the mole ratio of the reaction was found to be 1:1 (Fig. 1), and is represented below (Eq. 2).

$\mathrm{NR}^{+}+\mathrm{NO}_{2}^{-} \longrightarrow$ products

Similar stoichiometry has been reported in the reactions of nitrite. [3,4,5,7].

Kinetics. The result of kinetic studies were obtained by plotting $\log \left(\mathrm{A}_{\mathrm{t}}-\mathrm{A}_{\infty}\right)$ against time $\mathrm{t}$ (Fig. 2). The slope was calculated and $\mathrm{k}_{1}$ (pseudo-first order rate constant), was determined by multiplying the slope by 2.303 . The order of the reaction with respect to $\left[\mathrm{NO}_{2}^{-}\right]$was determined by plotting a graph of $\log \mathrm{k}_{1}$ against $\log \left[\mathrm{NO}_{2}{ }^{-}\right]$. The gradient of the linear graph was obtained as 0.99 (Fig. 3). The values of second order rate constants $\mathrm{k}_{2}$ determined as the ratio of $\mathrm{k}_{1}$ and $\left[\mathrm{NO}_{2}{ }^{-}\right]$were fairly constant (Table 1). The rate equation for the reaction can be written as;

$-\mathrm{d}\left[\mathrm{NR}^{+}\right] / \mathrm{dt}=\mathrm{k}_{2}\left[\mathrm{NR}^{+}\right]\left[\mathrm{NO}_{2}^{-}\right]$

Similar order was reported in the redox reactions of nitrite $[1,4,5,7]$.

Effect of $\left[\mathrm{H}^{+}\right]$. The effect of changes in $\left[\mathrm{H}^{+}\right]$on the reaction rate was investigated by varying the $\left[\mathrm{H}^{+}\right]$between $\left(1.0-7.0 \times 10^{-3} \mathrm{~mol} \mathrm{dm}^{-3}\right)$. The rate of reaction increased with increase in $\left[\mathrm{H}^{+}\right]$. The slope obtained from the plot of $\log \mathrm{k}_{1}$ versus $\log \left[\mathrm{H}^{+}\right]$, was 0.8 , which showed a first order dependence on $\left[\mathrm{H}^{+}\right]$. A plot of acid dependent second order rate constant $\mathrm{k}_{2}$ versus $\left[\mathrm{H}^{+}\right]$was also linear with an intercept (Figure 4). The nature of the acid dependence effect is expressed as;

$\mathrm{k}_{2}=\mathrm{a}+\mathrm{b}\left[\mathrm{H}^{+}\right]$

where $\mathrm{a}=1.41 \mathrm{dm}^{3} \mathrm{~mol}^{-1} \mathrm{~s}^{-1}$ and $\mathrm{b}=0.70 \mathrm{dm}^{6} \mathrm{~mol}^{-2} \mathrm{~s}^{-1}$

Acid dependence of this nature shows that there is a rapid pre-equilibrium between the protonated and non-protonated forms in which both forms are reactive [4]. The overall rate equation in the acid range investigated is given as:

$-\mathrm{d}\left[\mathrm{NR}^{+}\right] / \mathrm{dt}=\left(\mathrm{a}+\mathrm{b}\left[\mathrm{H}^{+}\right]\right)\left[\mathrm{NR}^{+}\right]\left[\mathrm{NO}_{2}^{-}\right]$

Similar acid dependence has been established $[6,7]$.

Effect of Ionic Strength and Dielectric Constant. The effect of varying the ionic strength on the rate of reaction as the concentration of other reactants were kept constant was investigated in the range of $(0.06-0.12) \mathrm{mol} \mathrm{dm}^{-3}$. The rate constants were observed to decrease with increase in ionic strength suggesting negative Bronsted - Debye salt effect (Figure 5) [13]. This indicates that the species at the rate determining step are of different charges. This result was supported by the observed decrease in the reaction rate as the dielectric constant of the medium was decreased (Table 2).

Effect of Added Ions. Added anions $\left(\mathrm{SO}_{4}{ }^{2-}\right.$ and $\left.\mathrm{NO}_{3}{ }^{-}\right)$(Table 3 ) had no effect on the rate of the reaction while added cations $\left(\mathrm{Mg}^{2+}\right.$ and $\mathrm{Ca}^{2+}$ ) (Table 3 and Figure 6) increased the reaction rate. This is an indication that the reaction might be operating via the outer sphere mechanism $[1,7]$.

Test for Intermediate Complex Formation. There was no clear shift in $\lambda_{\max }, 525 \mathrm{~nm}$, recorded when the spectrum of the reaction mixture was compared with that of $\left[\mathrm{NR}^{+}\right]$. Lack of spectrophotometric evidence for the formation of intermediate complex suggests an outer sphere mechanism. The Michaelis-Menton plot of $1 / \mathrm{k}_{1}$ versus $1 /\left[\mathrm{NO}_{2}{ }^{-}\right]$was linear with no intercept suggesting the absence of an intermediate complex formation (Figure 7).

Polymerization Studies. Addition of acrylamide to the partially reacted solution to serve as radical scavenger in the presence of large excess of methanol did not produce a gelatinous precipitate. This indicates that the involvement of free radicals in the reaction is unlikely. 
Reaction Mechanism. On the basis of the results above from our investigation, the following reaction scheme is proposed for this reaction:

$$
\begin{aligned}
& \mathrm{K} \\
& \mathrm{NO}_{2}^{-}+\mathrm{H}^{+} \rightleftharpoons \mathrm{HONO} \\
& \mathrm{HONO}+\mathrm{NR}^{+} \underset{\mathrm{k}_{4}}{\stackrel{\mathrm{k}_{3}}{\longrightarrow}}\left[\mathrm{HONO} / / \mathrm{NR}^{+}\right] \\
& \begin{array}{lll}
\mathrm{NO}_{2}^{-}+\mathrm{NR}^{+} \stackrel{\mathrm{k}_{5}}{\longrightarrow} & \mathrm{NRNO}_{2} \\
{\left[\mathrm{HONO} / / \mathrm{NR}^{+}\right] \stackrel{\text { Products }}{\longrightarrow}}
\end{array} \\
& \mathrm{NRNO}_{2} \stackrel{\mathrm{k}_{6}}{\longrightarrow} \quad \text { Products } \\
& \text { Rate }=\mathrm{k}_{3}[\mathrm{HONO}]\left[\mathrm{NR}^{+}\right]+\mathrm{k}_{4}\left[\mathrm{NO}_{2}{ }^{-}\right]\left[\mathrm{NR}^{+}\right] \\
& {[\mathrm{HONO}]=\mathrm{K}\left[\mathrm{NO}_{2}^{-}\right]\left[\mathrm{H}^{+}\right]} \\
& \text {Rate }=\left(\mathrm{k}_{4}+\mathrm{k}_{3} \mathrm{~K}\left[\mathrm{H}^{+}\right]\right)\left[\mathrm{NO}_{2}^{-}\right]\left[\mathrm{NR}^{+}\right] \\
& \text {Rate }=\mathrm{k}^{\prime}\left[\mathrm{NO}_{2}^{-}\right]\left[\mathrm{NR}^{+}\right] \\
& \mathrm{k}^{\prime}=\mathrm{k}_{4}+\mathrm{k}_{3} \mathrm{~K}\left[\mathrm{H}^{+}\right]
\end{aligned}
$$

\begin{tabular}{|c|c|c|c|c|}
\hline $\begin{array}{l}\mathbf{1 0}^{3}\left[\mathrm{NO}_{2}{ }^{-}\right] \\
\left(\mathrm{mol} \mathrm{dm}^{-3}\right)\end{array}$ & $\begin{array}{c}\mathbf{1 0}^{3}\left[\mathbf{H}^{+}\right] \\
\left(\mathbf{m o l ~ d m}^{-3}\right)\end{array}$ & $\begin{array}{c}10 \mathrm{I}, \\
\left(\mathrm{mol} \mathrm{dm}^{-3}\right)\end{array}$ & $\begin{array}{c}10^{3} k_{1}, \\
\left(s^{-1}\right)\end{array}$ & $\begin{array}{c}k_{2}, \\
\left(\mathrm{dm}^{3} \mathrm{~mol}^{-1} \mathrm{~s}^{-1}\right)\end{array}$ \\
\hline 0.8 & 2.0 & 1.0 & 2.63 & 3.29 \\
\hline 1.0 & 2.0 & 1.0 & 3.13 & 3.13 \\
\hline 1.2 & 2.0 & 1.0 & 3.96 & 3.30 \\
\hline 1.4 & 2.0 & 1.0 & 4.58 & 3.27 \\
\hline 1.6 & 2.0 & 1.0 & 5.25 & 3.28 \\
\hline 1.8 & 2.0 & 1.0 & 5.78 & 3.21 \\
\hline 2.0 & 2.0 & 1.0 & 6.29 & 3.15 \\
\hline 2.3 & 2.0 & 1.0 & 7.48 & 3.25 \\
\hline 1.2 & 1.0 & 1.0 & 2.81 & 2.34 \\
\hline 1.2 & 2.0 & 1.0 & 3.94 & 3.28 \\
\hline 1.2 & 3.0 & 1.0 & 5.94 & 4.95 \\
\hline 1.2 & 4.0 & 1.0 & 7.81 & 6.51 \\
\hline 1.2 & 5.0 & 1.0 & 8.87 & 7.39 \\
\hline 1.2 & 6.0 & 1.0 & 10.82 & 9.02 \\
\hline 1.2 & 7.0 & 1.0 & 13.01 & 10.84 \\
\hline 1.2 & 2.0 & 0.6 & 6.10 & 5.08 \\
\hline 1.2 & 2.0 & 0.7 & 5.78 & 4.82 \\
\hline 1.2 & 2.0 & 0.8 & 5.09 & 4.24 \\
\hline 1.2 & 2.0 & 0.9 & 4.49 & 3.74 \\
\hline 1.2 & 2.0 & 1.0 & 3.96 & 3.30 \\
\hline 1.2 & 2.0 & 1.1 & 3.59 & 2.99 \\
\hline 1.2 & 2.0 & 1.2 & 3.32 & 2.77 \\
\hline
\end{tabular}

Table 1: The pseudo-first order and second order rate constants for the reaction of $\mathrm{NR}^{+}$ and $\mathrm{NO}_{2}^{-}$at $\left[\mathrm{NR}^{+}\right]=\mathbf{2 . 0 \times 1 0 ^ { - 5 }} \mathrm{mol} \mathrm{dm}^{-3}, \mathrm{~T}=25 \pm 1{ }^{\circ} \mathrm{C}$ and $\lambda_{\max }=525 \mathrm{~nm}$ 
Table 2: Effect of Dielectric constant on the rate of reaction of $\mathrm{NR}^{+}$and $\mathrm{NO}_{2}^{-}$at $\left[\mathrm{NR}^{+}\right]=2.0 \times 10^{-5} \mathrm{~mol} \mathrm{dm}^{-3},\left[\mathrm{NO}_{2}^{-}\right]=1.2 \times 10^{-3} \mathrm{~mol} \mathrm{dm}^{-3}, \mathrm{I}=0.1 \mathrm{~mol} \mathrm{dm}^{-3}$, $\left[\mathrm{H}^{+}\right]=2.0 \times 10^{-3} \mathrm{~mol} \mathrm{dm}^{-3}, \mathrm{~T}=25 \pm 1^{\circ} \mathrm{C}$ and $\lambda_{\max }=525 \mathrm{~nm}$

\begin{tabular}{ccc}
\hline $\mathrm{D}$ & $10^{3} \mathrm{k}_{1},\left(\mathrm{~s}^{-1}\right)$ & $\mathrm{k}_{2},\left(\mathrm{dm}^{3} \mathrm{~mol}^{-1} \mathrm{~s}^{-1}\right)$ \\
\hline 81.00 & 3.94 & 3.28 \\
80.18 & 3.20 & 2.66 \\
79.35 & 2.38 & 2.30 \\
78.53 & 2.08 & 1.73 \\
77.71 & 1.78 & 1.48 \\
76.88 & 1.44 & 1.20 \\
76.06 & 1.04 & 0.87 \\
\hline
\end{tabular}

Table 3: Effect of added anion and cation on the rate of reaction of $\mathrm{NR}^{+}$and $\mathrm{NO}_{2}^{-}$at $\left[\mathrm{NR}^{+}\right]=2.0 \times 10^{-5} \mathrm{~mol} \mathrm{dm}^{-3},\left[\mathrm{NO}_{2}^{-}\right]=1.2 \times 10^{-3} \mathrm{~mol} \mathrm{dm}^{-3}, \mathrm{I}=0.1 \mathrm{~mol} \mathrm{dm}^{-3}$, $\left[\mathrm{H}^{+}\right]=2.0 \times 10^{-3} \mathrm{~mol} \mathrm{dm}^{-3}, \mathrm{~T}=25 \pm 1^{\circ} \mathrm{C}$ and $\lambda_{\max }=525 \mathrm{~nm}$

\begin{tabular}{|c|c|c|c|}
\hline$X$ & $10^{3}[\mathrm{X}],\left(\mathrm{mol} \mathrm{dm}^{-3}\right)$ & $10^{3} \mathrm{k}_{1},\left(\mathrm{~s}^{-1}\right)$ & $\mathrm{k}_{2},\left(\mathrm{dm}^{3} \mathrm{~mol}^{-1} \mathrm{~s}^{-1}\right)$ \\
\hline \multirow[t]{7}{*}{$\mathrm{SO}_{4}{ }^{2-}$} & 0.0 & 3.96 & 3.30 \\
\hline & 1.0 & 3.98 & 3.32 \\
\hline & 2.0 & 3.94 & 3.28 \\
\hline & 3.0 & 3.98 & 3.32 \\
\hline & 4.0 & 4.01 & 3.34 \\
\hline & 6.0 & 3.94 & 3.28 \\
\hline & 8.0 & 3.96 & 3.30 \\
\hline \multirow[t]{7}{*}{$\mathrm{NO}_{3}^{-}$} & 0.0 & 3.94 & 3.28 \\
\hline & 1.0 & 3.98 & 3.32 \\
\hline & 2.0 & 3.96 & 3.30 \\
\hline & 3.0 & 3.98 & 3.32 \\
\hline & 4.0 & 3.98 & 3.32 \\
\hline & 6.0 & 3.94 & 3.28 \\
\hline & 8.0 & 3.96 & 3.30 \\
\hline \multirow[t]{7}{*}{$\mathrm{Mg}^{2+}$} & 0.0 & 3.94 & 3.28 \\
\hline & 1.0 & 4.35 & 3.63 \\
\hline & 2.0 & 4.77 & 3.98 \\
\hline & 3.0 & 5.04 & 4.20 \\
\hline & 4.0 & 5.41 & 4.51 \\
\hline & 6.0 & 6.15 & 5.13 \\
\hline & 8.0 & 6.79 & 5.66 \\
\hline \multirow[t]{7}{*}{$\mathrm{Ca}^{2+}$} & 0.0 & 3.96 & 3.30 \\
\hline & 1.0 & 4.38 & 3.65 \\
\hline & 2.0 & 4.68 & 3.90 \\
\hline & 3.0 & 5.20 & 4.30 \\
\hline & 4.0 & 5.44 & 4.53 \\
\hline & 6.0 & 6.15 & 5.13 \\
\hline & 8.0 & 7.07 & 5.89 \\
\hline
\end{tabular}




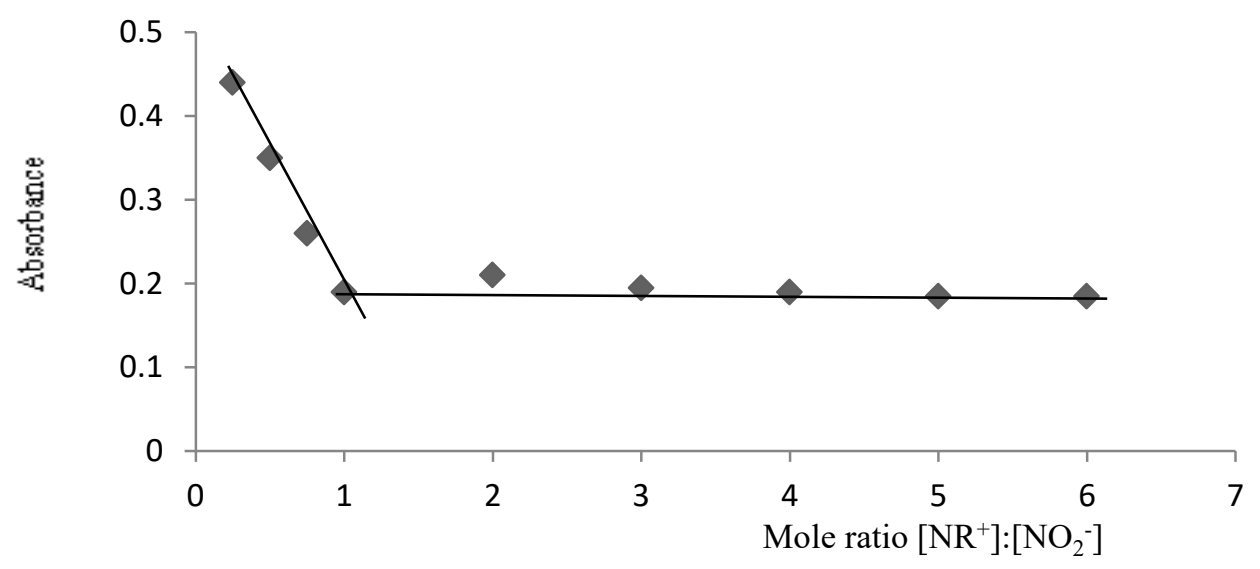

Figure 1: Plot of Absorbance versus mole ratio for the redox reaction of $\mathrm{NR}^{+}$with $\mathrm{NO}_{2}^{-}$at $\left[\mathrm{NR}^{+}\right]=2.0 \times 10^{-5} \mathrm{~mol} \mathrm{dm}^{-3}, \mathrm{I}=0.1 \mathrm{~mol} \mathrm{dm}^{-3},\left[\mathrm{H}^{+}\right]=2.0 \times 10^{-3} \mathrm{~mol} \mathrm{dm}^{-3}, \mathrm{~T}=25 \pm 1^{\circ} \mathrm{C}$ and $\lambda_{\max }=525 \mathrm{~nm}$.

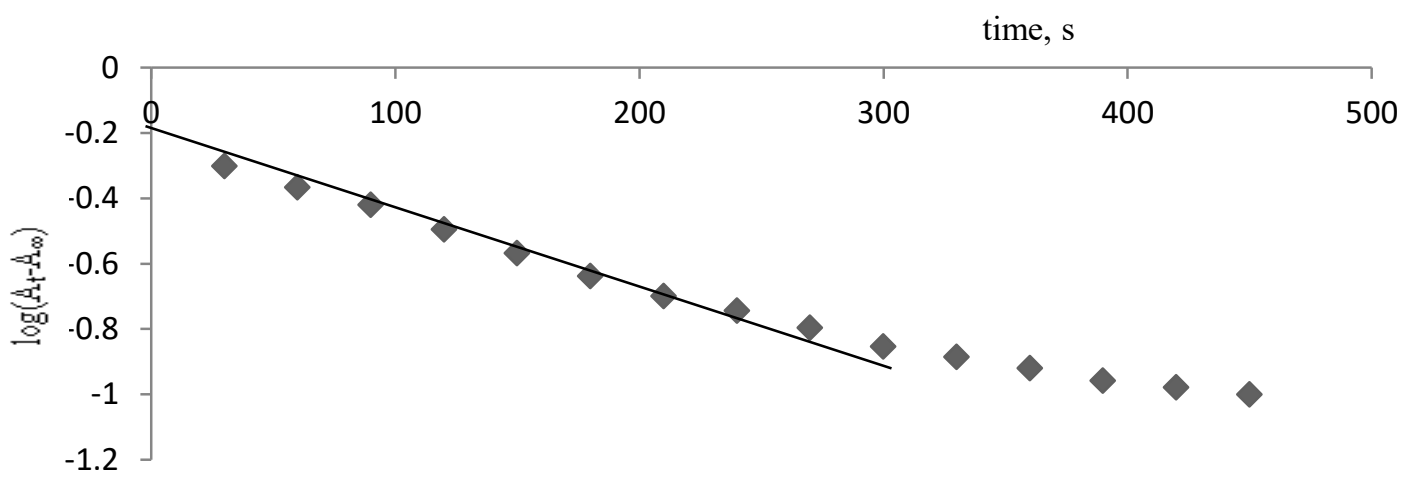

Figure 2: Typical pseudo-first order plot for the redox reaction of $\mathrm{NR}^{+}$with $\mathrm{NO}_{2}^{-}$at $\left[\mathrm{NR}^{+}\right]=2.0 \times 10^{-5} \mathrm{~mol} \mathrm{dm}^{-3},\left[\mathrm{NO}_{2}^{-}\right]=1.2 \times 10^{-3} \mathrm{~mol} \mathrm{dm}^{-3}, \mathrm{I}=0.1 \mathrm{~mol} \mathrm{dm}^{-3}$, $\left[\mathrm{H}^{+}\right]=2.0 \times 10^{-3} \mathrm{~mol} \mathrm{dm}^{-3}, \mathrm{~T}=25 \pm 1^{\circ} \mathrm{C}$ and $\lambda_{\max }=525 \mathrm{~nm}$.

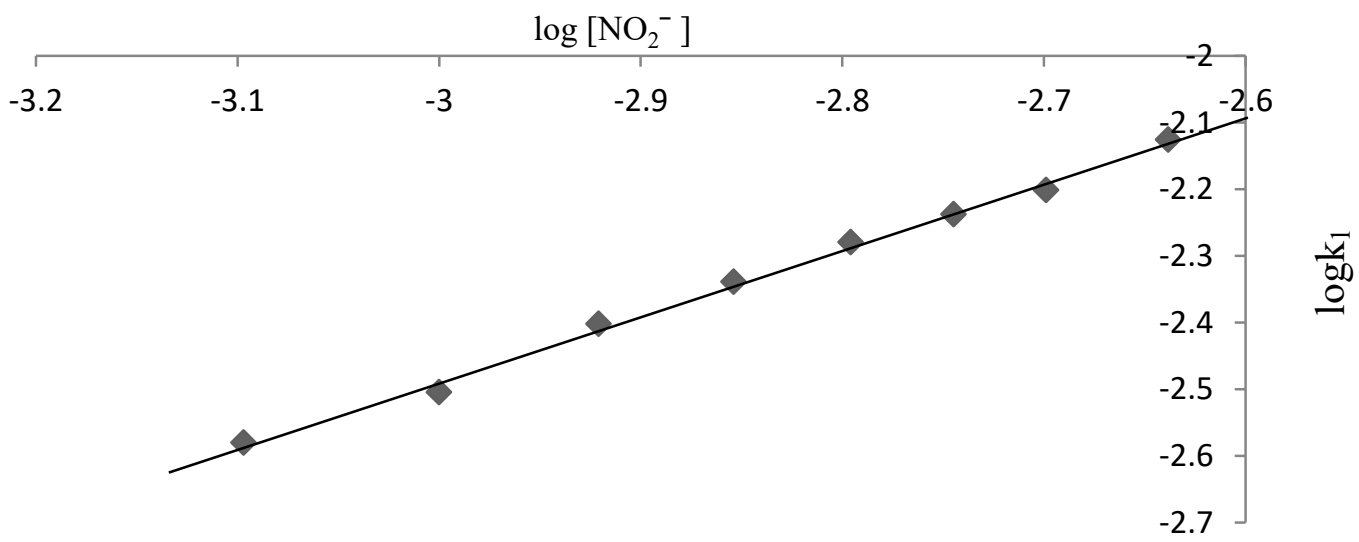

Figure 3: Plot of $\log \mathrm{k}_{1}$ versus $\log \left[\mathrm{NO}_{2}^{-}\right]$for the redox reaction of $\mathrm{NR}^{+}$with $\mathrm{NO}_{2}^{-}$at $\left[\mathrm{NR}^{+}\right]=2.0 \times 10^{-5} \mathrm{~mol} \mathrm{dm} \mathrm{dm}^{-3}, \mathrm{I}=0.1 \mathrm{~mol} \mathrm{dm}^{-3},\left[\mathrm{H}^{+}\right]=2.0 \times 10^{-3} \mathrm{~mol} \mathrm{dm}^{-3}$, $\mathrm{T}=25 \pm 1{ }^{\circ} \mathrm{C}$ and $\lambda_{\max }=525 \mathrm{~nm}$. 


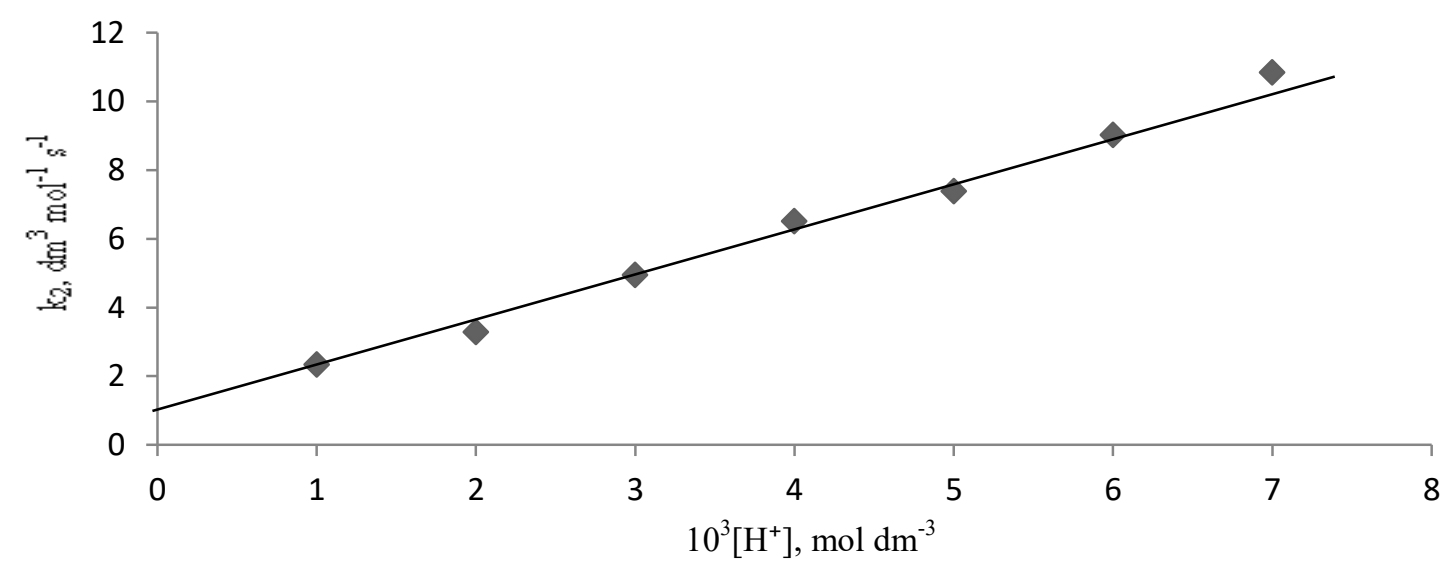

Figure 4: Plot of $\mathrm{k}_{2}$ versus $10^{3}\left[\mathrm{H}^{+}\right]$for the redox reaction of $\mathrm{NR}^{+}$with $\mathrm{NO}_{2}^{-}$at $\left[\mathrm{NR}^{+}\right]=2.0 \times 10^{-5} \mathrm{~mol} \mathrm{dm}^{-3},\left[\mathrm{NO}_{2}^{-}\right]=1.2 \times 10^{-3} \mathrm{~mol} \mathrm{dm}^{-3}, \mathrm{I}=0.1 \mathrm{~mol} \mathrm{dm}^{-3}$, $\mathrm{T}=25 \pm 1{ }^{\circ} \mathrm{C}$ and $\lambda_{\max }=525 \mathrm{~nm}$

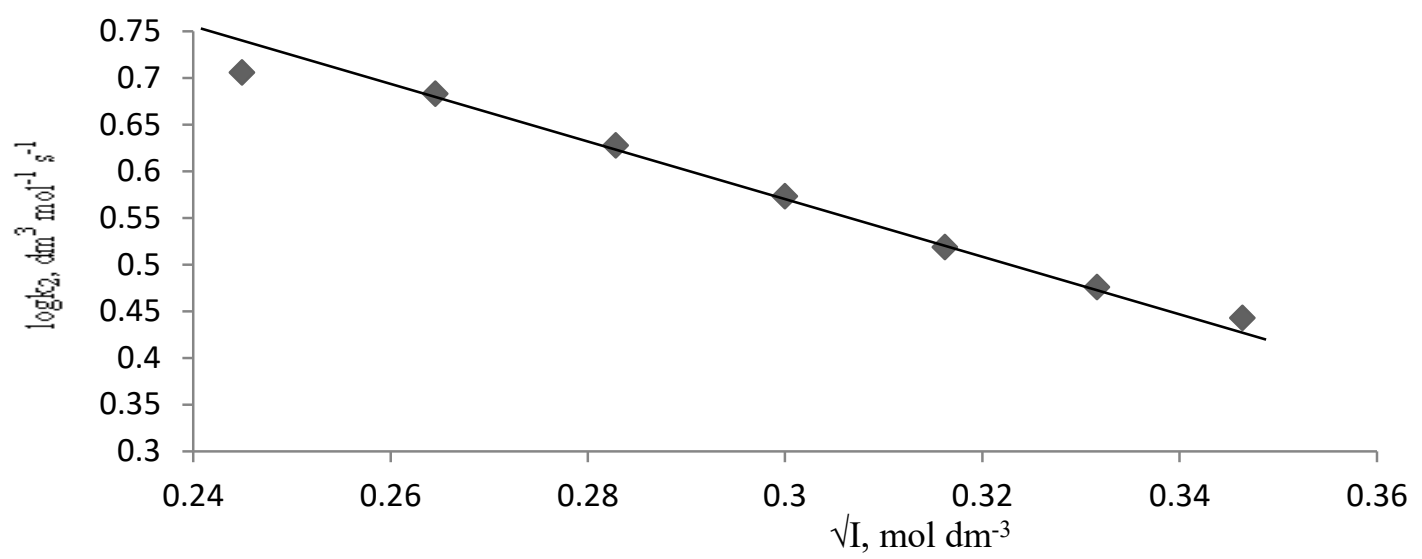

Figure 5: Plot of $\log k_{2}$ versus $\sqrt{ }$ I for the redox reaction of $\mathrm{NR}^{+}$with $\mathrm{NO}_{2}^{-}$at $\left[\mathrm{NR}^{+}\right]=2.0 \times 10^{-5} \mathrm{~mol} \mathrm{dm}^{-3},\left[\mathrm{NO}_{2}^{-}\right]=1.2 \times 10^{-3} \mathrm{~mol} \mathrm{dm}^{-3}$, $\left[\mathrm{H}^{+}\right]=2.0 \times 10^{-3} \mathrm{~mol} \mathrm{dm}^{-3}, \mathrm{~T}=25 \pm 1{ }^{\circ} \mathrm{C}$ and $\lambda_{\max }=525 \mathrm{~nm}$

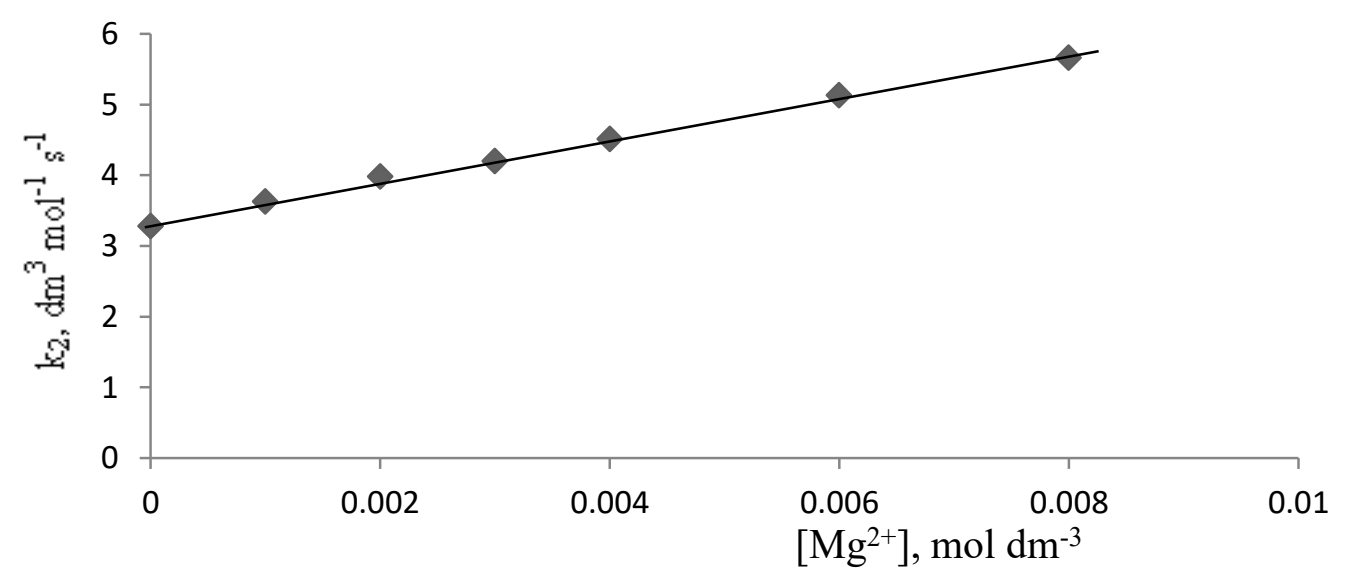

Figure 6: Plot of $\mathrm{k}_{2}$ versus $\left[\mathrm{Mg}^{2+}\right]$ for the redox reaction of $\mathrm{NR}^{+}$with $\mathrm{NO}_{2}^{-}$at $\left[\mathrm{NR}^{+}\right]=2.0 \times 10^{-5} \mathrm{~mol} \mathrm{dm}^{-3},\left[\mathrm{NO}_{2}^{-}\right]=1.2 \times 10^{-3} \mathrm{~mol} \mathrm{dm}^{-3}, \mathrm{I}=0.1 \mathrm{~mol} \mathrm{dm}^{-3}$, $\left[\mathrm{H}^{+}\right]=\mathbf{2 . 0} \times \mathbf{1 0}^{-3} \mathrm{~mol} \mathrm{dm}^{-3}, \mathrm{~T}=25 \pm 1{ }^{\circ} \mathrm{C}$ and $\lambda_{\max }=525 \mathrm{~nm}$ 


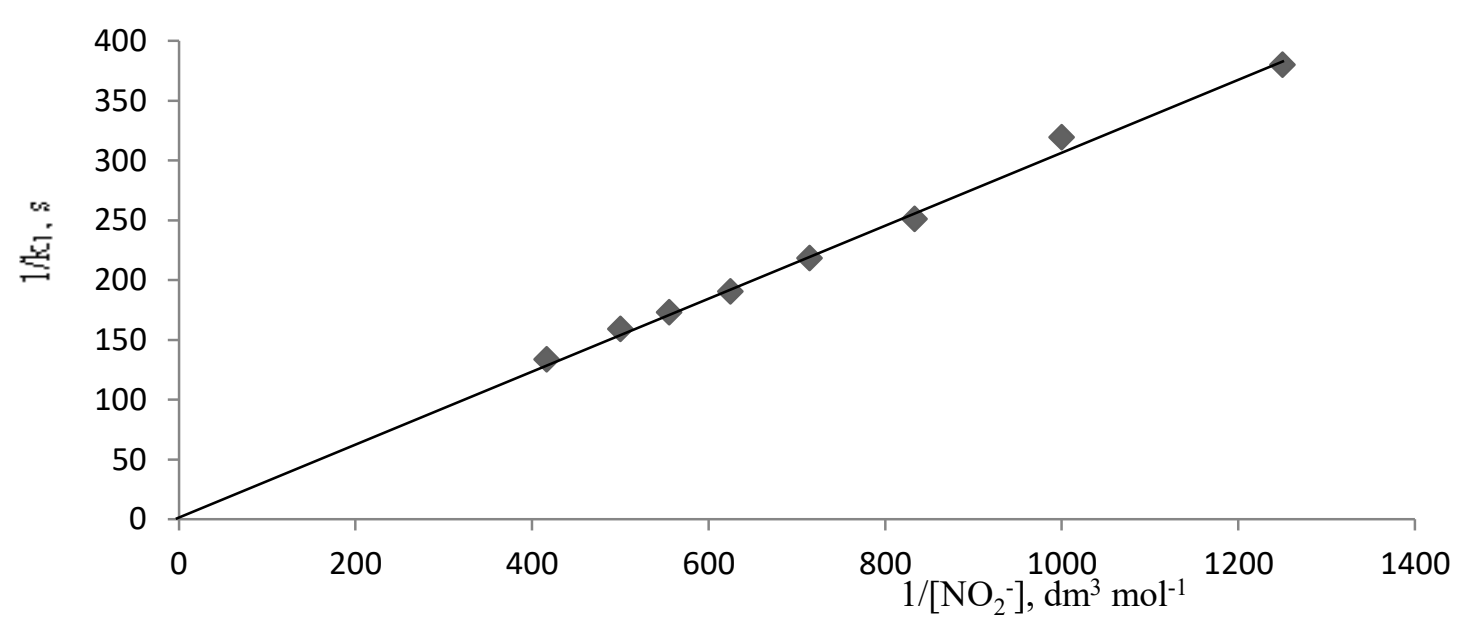

Figure 7: Michaelis-Menten plot for the redox reaction of $\mathrm{NR}^{+}$with $\mathrm{NO}_{2}^{-}$at
$\left[\mathrm{NR}^{+}\right]=2.0 \times 10^{-5} \mathrm{~mol} \mathrm{dm}, \mathrm{I}=0.1 \mathrm{~mol} \mathrm{dm}{ }^{-3},\left[\mathrm{H}^{+}\right]=2.0 \times 10^{-3} \mathrm{~mol} \mathrm{dm}^{-3}$
$\mathrm{~T}=25 \pm 1{ }^{\circ} \mathrm{C}$ and $\lambda_{\max }=525 \mathrm{~nm}$

\section{Conclusion}

The redox reaction of neutral red with nitrite ion in aqueous acidic medium showed a stoichiometry of $1: 1$. The reaction is second order overall. The reaction showed both acid dependent and independent pathways. It also displayed a negative Bronsted-Debye salt effect. Both kinetic and spectroscopic investigations showed no evidence of intermediate complex formation. Based on the foregoing, the outer sphere mechanism is proposed as the plausible mechanistic pathway for this reaction.

\section{References}

[1] S.A. Hamza, J.F. Iyun, S.O Idris, Kinetics and mechanism of the redox reaction of toluidine blue and nitrite ions in aqueous acidic medium. Arch. App. Sci. Res. 4 (2012) 10-18.

[2] L. Rong, C.Y. Jimmy, J. Zi-Tao, Z. Ren-Hua, L. Ho-Yan, A solid-phase fluorescent quenching method for the determination of trace amounts of nitrite in foods with neutral red. J. Food Drug Anal. 11 (2003) 251-257.

[3] A.D. Onu, J.F. Iyun and S.O. Idris, Redox reaction of [Co(II)HEDTA] with $\mathrm{NO}_{2}^{-}$in aqueous perchloric acid medium; Kinetics and Mechanism. ChemClass J. 5 (2008) 55-61.

[4] A.D. Onu, J.F. Iyun, Kinetics and mechanism for oxidation of rosaniline monochloride by nitrite ions. J. Chem. Res. 3 (1998) 25-26.

[5] O.A. Babatunde, Kinetics and mechanism of reduction of parafuchsin by nitrite ions in aqueous acid medium. World J. Chem. 4 (2009) 39-44.

[6] A. Adetoro, J.F Iyun, S.O. Idris, Kinetic approach to the mechanism of redox reaction of pyrocatechol violet and nitrite ion in aqueous hydrochloric acid. Res. J. App. Sci. Eng. Tech. 3 (2011) 1159-1163.

[7] S.O Idris, V.O. Samson, B. Myek, Kinetics of the oxidation of bromopyrogallol red by nitrite ion in aqueous acidic medium. International Frontier Science Letters, 3 (2015) 32-38.

[8] J. Winckler, Vital staining of lysosomes and other cell organelles of the rat with neutral Red. Prog. Histochem. Cytochem. 6 (1974) 1-89. 
[9] G. Repetto, A. del Peso, J.L. Zurita, Neutral red uptake assay for the estimation of cell viability/cytotoxicity. Nat. Protoc. 3 (2008) 1125-1131.

[10] I.A. Salem, Kinetics and mechanisms of the non-catalyzed and manganese(II) catalyzed oxidation of neutral red with potassium periodate in aqueous solution. Zeitschrift für physikalische Chemie. 216 (2002) 991-1003.

[11] M.N. Khan, Z. Siddiquib, F. Uddinc, Kinetic and mechanism study of the oxidative decolorization of neutral red by bromate in micellar medium. J. Iran. Chem. Soc. 6 (2008) 533-541.

[12] Hamza, S. A., J. F. Iyun, and S. O. Idris, Kinetics approach to the Mechanism of the reduction of toluidine blue by ascorbic acid. Scholars Research Library. Der Pharma Chemica 4.1 (2012) 1-9.

[13] D. Benson, Mechanism of Inorganic Reactions in Solution. Mc Graw- Hill U.K., 1969. 